\title{
Nesidiocoris tenuis (Reuter) (Heteroptera: Miridae), a predatory species of the tomato leafminer, Tuta absoluta (Meyrick) (Lepidoptera: Gelechiidae) in Iran
}

\author{
Fariba Sohrabi ${ }^{1 *}$, Reza Hosseini ${ }^{2}$ \\ ${ }^{1}$ Department of Plant Breeding, Faculty of Agriculture, Persian Gulf University, P.O. Box 75169-13798, Busher, Iran \\ ${ }^{2}$ Department of Plant Protection, Faculty of Agriculture, Guilan University, 41889-58643 Guilan, Iran
}

Received: January 28, 2015

Accepted: June 19, 2015

\begin{abstract}
The tomato leafminer, Tuta absoluta (Meyrick), is a major worldwide pest of tomato crops, both in the greenhouse and in open field cultivations. Since this pest's new introduction in Iran, it has caused extensive damage. Chemicals have mainly been used to control this pest. The purpose of our research was to identify the indigenous predators of the tomato leafminer, associated with tomato in the Borazjan region of the Bushehr province, Iran. From March to May 2014, infested tomato leaves were collected from protected tomato crops. A predator species from the family Miridae was found, reared, and identified as Nesidiocoris tenuis (Reuter 1895). This species is reported for the first time on tomato leafminer in Iran. Identification of important natural enemies provides a scientific basis for including these predators in the biological programs against this pest.
\end{abstract}

Key words: Nesidiocoris tenuis, predator, tomato, Tuta absoluta

\section{Introduction}

Tuta absoluta (Meyrick) (Lepidoptera: Gelechiidae) is an important tomato pest native to South America (Luna et al. 2011; Guedes and Picanço 2012). Since its initial discovery in Iran (Baniameri and Cheraghian 2011, 2012), this pest has caused significant damage to tomato crops, both in greenhouses and in the open field (Sohrabi et al. 2014). Throughout Iran, tomato producers routinely use insecticides of different groups against T. absoluta. But the insecticides may cause adverse environmental effects. Biological control is a promising alternative and is one of the main methods since it saves the natural enemies. Therefore, we aimed to conduct a survey of indigenous predators attacking T. absoluta in the Borazjan region of the Bushehr province, Iran.

\section{Materials and Methods}

Samplings were conducted in six heavily, leafminer-infested, tomato fields in the Bondarooz, Borazjan region, the Bushehr province (Southern Iran) from March to the end of May 2014. Geographical coordinates for study sites were as followed:

site 1: $29^{\circ} 12^{\prime} 47.4^{\prime \prime} \mathrm{N}, 51^{\circ} 13^{\prime} 56^{\prime \prime}$ E, elev. 90 m;

site 2: $29^{\circ} 12^{\prime} 54.1^{\prime \prime} \mathrm{N}, 51^{\circ} 13^{\prime} 57.1^{\prime \prime}$ E, elev. $99 \mathrm{~m}$;

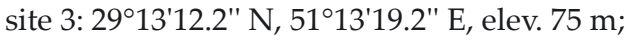

site 4: $29^{\circ} 13^{\prime} 35.1^{\prime \prime} \mathrm{N}, 5^{\circ} 13^{\prime} 4^{\prime \prime}$ E, elev. $106 \mathrm{~m}$; site 5: $2^{\circ} 13^{\prime} 52.9^{\prime \prime} \mathrm{N}, 51^{\circ} 12^{\prime} 35.8^{\prime \prime}$ E, elev. $76 \mathrm{~m}$;

site 6: $29^{\circ} 14^{\prime} 7.7^{\prime \prime} \mathrm{N}, 51^{\circ} 12^{\prime} 38.5^{\prime \prime}$ E, elev. $75 \mathrm{~m}$.

The plant samples were transferred to the laboratory and examined leaf by leaf for predators. The specimens were collected using an aspirator and kept in a small vial containing $70 \%$ alcohol and sent to the second author to confirm the preliminary identification. The specimens are deposited in the insect collection of the Natural Museum of Guilan University, Guilan, Iran.

\section{Results and Discussion}

One species belonging to the Miridae family was found in association with T. absoluta and identified as Nesidiocoris tenuis (Reuter 1895) (Hemiptera: Miridae) (Fig. 1). The important diagnostic characters of this species are as follows:

Body size 3-3.3 mm. Pale whitish green. Ocular index: 1.3-1.5. Left paramer very slender, strongly curved sickleshaped. Middle of the first segment, and base of the second segment of antenna - black. A dark ring at the apex of the 2nd antennal segment, 3rd and 4th segment - brown. At the rear edge of the corium there was a small dark brown spot and at the tip of the cuneus there was a small dark brown spot. Membrane - gray, veins - brown. Base of the tibia (knee) narrowly black (Hosseini 2013). 


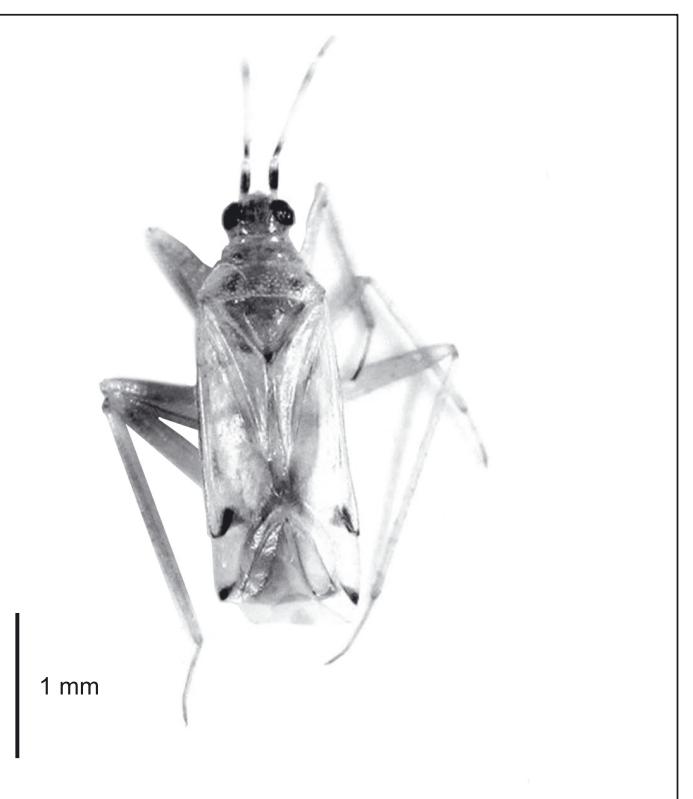

Fig. 1. The adult predator Nesidiocoris tenuis (Hemiptera: Miridae)

This species has been reported from Mediterranean countries to Europe, North Africa, Middle East, Japan, Australia, Pacific Islands, North America, Cuba, Venezuela (Kerzhner and Josifov 1999; Zappala et al. 2013), and Iran (Linnavuori 2007). Nesidiocoris tenuis is known to contribute to the control of such pests as whiteflies, thrips, lepidopteran, and several other pest species in greenhouses (Marcos and Rejesus 1992; Carnero et al. 2000; Calvo et al. 2009; Hughes et al. 2009). This predator has a low damage potential on tomato plants. This is true even when this predator occurs at high densities (Perdikis et al. 2009). The tomato leafminer, T. absoluta, has been recorded as prey for $N$. tenuis in many countries (Urbaneja et al. 2009; Molla et al. 2011; El-Arnaouty and Kortam 2012; Al-Jboory et al. 2012). This is the first record of $N$. tenuis on T. absoluta from Iran. Its effectiveness in the biological or integrated control programmes of T. $a b$ soluta remains to be evaluated.

\section{References}

Al-Jboory I.J., Katbeh-Bader A., Al-Zaidi S. 2012. First observation and identification of some natural enemies collected from heavily infested tomato by Tuta absoluta (Meyrick) (Lepidoptera: Gelechiidae) in Jordan. Middle-East Journal of Scientific Research 11 (4): 435-438.

Baniameri V., Cheraghian A. 2011. The current status of Tuta absoluta in Iran and initial control strategies. p. 20. In: “EPPO/ IOBC/FAO/NEPPO Joint International Symposium on management of Tuta absoluta (tomato borer)". Agadir, Morocco, 16-18 November 2011.

Baniameri V., Cheraghian A. 2012. The first report and control strategies of Tuta absoluta in Iran. EPPO Bulletin 42 (2): 322-324.
Calvo J., Bolckmans K., Stansly P.A., Urbaneja A. 2009. Predation by Nesidiocoris tenuis on Bemisia tabaci and injury to tomato. BioControl 54 (2): 237-246.

Carnero-Hernández A., Díaz-Hernández S., Amador-Martín S., Hernández-García M., Hernández-Suárez E. 2000. Impact of Nesidiocoris tenuis Reuter (Hemiptera: Miridae) on whitefly populations in protected tomato crops. IOBC/ WPRS Bulletin 23 (1): 259.

El-Arnaouty S.A., Kortam M.N. 2012. First record of the mired predatory species, Nesidiocoris tenuis Reuter (Heteroptera: Miridae) on the tomato leafminer, Tuta absoluta (Meyrick) (Lepidoptera: Gelechiidae) in Egypt. Egyptian Journal of Biological Pest Control 22 (2): 223-224.

Guedes R.N.C., Picanço M.C. 2012. The tomato borer Tuta absolut $a$ in South America: pest status, management and insecticide resistance. EPPO Bulletin 42 (2): 211-216.

Hosseini R. 2013. On the tribe Dicyphini (Hemiptera: Heteroptera: Miridae: Bryocorinae) in Guilan province and adjacent area (Iran). Entomofauna 34 (11): 157-158.

Hughes G.E., Bale J.S., Sterk G. 2009. Thermal biology and establishment potential in temperate climates of the predatory mirid Nesidiocoris tenuis. BioControl 54 (6): 785-795.

Kerzhner I.M., Josifov M. 1999. Cimicomorpha II: Miridae. Vol. 3. In: "Catalogue of the Heteroptera of the Palaearctic Region" (B. Aukema, C. Rieger, eds). Wageningen, The Netherlands, $577 \mathrm{pp}$.

Linnavuori R.E. 2007. Studies on the Miridae (Heteroptera) of Gilan and the adjacent provinces in northern Iran. II. List of species. Acta Entomologica Musei Nationalis Pragae 47: $17-56$.

Luna M.G., Wada V.I., La Salle J., Sanchez N.E. 2011. Neochrysocharis formosa (Westwood) (Hymenoptera: Eulophidae), a newly recorded parasitoid of the tomato moth, Tuta absoluta (Meyrick) (Lepidoptera: Gelechiidae) in Argentina. Neotropical Entomology 40 (3): 412-414.

Marcos T.F., Rejesus R.S. 1992. Population dynamics of Helicoverpa spp. in tobacco growing areas of Locos Norte and La Uninos. Philippine Entomologist 8: 1227-1246.

Mollá O., González-Cabrera J., Urbaneja A. 2011. The combined use of Bacillus thuringiensis and Nesidiocoris tenuis against the tomato borer Tuta absoluta. BioControl 56 (6): 883-891.

Perdikis D., Fantinou A., Garantonakis N., Kitsis P., Maselou D., Panagakis S. 2009. Studies on the damage potential of the predator Nesidiocoris tenuis on tomato plants. Bulletin of Insectology 62 (1): 41-46.

Sohrabi F., Lotfalizadeh H., Salehipour H. 2014. Report of a larval parasitoid of Tuta absoluta (Meyrick) (Lepidoptera: Gelechiidae) from Iran. Journal of Plant Protection Research 54 (3): 306-307.

Urbaneja A., Montón H., Mollá O. 2009. Suitability of the tomato borer Tuta absoluta as prey for Macrolophus pygmaeus and Nesidiocoris tenuis. Journal of Applied Entomology 133 (4): 292-296.

Zappala L., Biondi A., Alma A., Al-Jboory I.J., Arno J., Bayram A., Desneux N. 2013. Natural enemies of the South American moth, Tuta absoluta, in Europe, North Africa and Middle East, and their potential use in pest control strategies. Journal of Pest Science 86 (4): 635-647. 